\title{
PELATIHAN PEMBUATAN SELAI LABU PARANG UNTUK MENINGKATKAN EKONOMI KELUARGA BAGI RT 013/01 KELURAHAN PASAR REBO JAKARTA TIMUR
}

\author{
Mariani \\ Tata Boga, IKK, Fakultas Teknik Universitas Negeri Jakarta
}

\begin{abstract}
ABSTRAK
Dalam upaya pelatihan pembuatan selai labu parang untuk meningkatkan ekonomi keluarga bagi RT 013/01 kelurahan pasa rebo, Jakarta Timur. Dalam pelatihan ini peserta diberikan materi, pengetahuan serta dipraktekan cara membuat selai labu parang. Khalayak sasaran dari pengabdian ini adalah Ibu-ibu RT 013/01 Kelurahan Pasar Rebo, Jakarta Timur. Biaya pengabdian diperoleh dari biaya DIPA PNBP UNJ tahun anggaran 2014. Kegiatan pengabdian telah dilaksanakan pada bulan Agustus yang bertempat di Kelurahan Pasar Rebo yang dihadiri oleh 20 peserta. Setiap peserta pada awalnya diberikan penyuluhan serta manfaat buah labu parang serta membuat selai labu parang. Latihan ini bertujuan untuk melatih peserta dalam meningkatkan kreatifitasnya dan meningkatkan ekonomi keluarga dengan keterampilan yang didapat. Dari hasil evaluasi diperoleh hasil dan manfaat dari kegiatan pengabdian ini diantaranya adalah kemampuan ibu-ibu untuk membuat selai labu parang.
\end{abstract}

Kata Kunci : Labu Parang, Ibu-ibu Kelurahan pasar Rebo

\section{PENDAHULUAN}

Potensi sumber daya tumbuhan dan buah buahan yang ada di Indonesia merupakan suatu aset dengan nilai keunggulan komparatif dan sebagai modal dasar utama dalam upaya pemanfaatan dan pengembangannya untuk komoditi yang kompetitif.

Sekian banyaknya komoditi yang ada salah satunya adalah buah labu parang. Labu parang (Cucurbita moschata) paling sering digunakan dalam masakan. Beragam jenis hidangan dapat dibuat dari buah ini, mulai dari kolak, sup, cake, hingga kue-kue basah seperti talam dan kue lumpur.

Labu kuning yang dikenal dengan sebutan labu parang ini kaya akan vitamin dan mineralnya cukup tinggi, meliputi: betakaroten, vitamin $\mathrm{B} 1$, vitamin $\mathrm{C}$, kalsium, fosfor, besi, kalium, dan natrium. Dari gizinya pun tidak mengecewakan, setiap 100 gr labu mengandung $34 \mathrm{kal}, 1.1$ protein, 0.3 lemak, 0.8 mineral, dan $45 \mathrm{mg}$ kalsium.

Pemilihan bahan dasar olahan menjadi salah satu indikator penting dalam menciptakan produk yang berkualitas. Labu parang (Cucurbita Moschata) merupakan salah satu bahan yang dapat dijadikan suatu produk yaitu selai. Labu parang merupakan buah-buahan yang dapat kita jumpai dengan mudah. Nutrisi yang dikandungnya menjadikan labu parang berkhasiat meningkatkan kekebalan tubuh. Betakaroten yang dikandung labu kuning berperan mencegah serangan jantung. Sementara kandungan vitamin B1, $\mathrm{C}$, dan seratnya berperan sebagai pencegah penyakit jantung dan stroke.

Ibu-ibu RT 013/01 Kelurahan Pasar Rebo, Jakarta Timur ini pada umumnya masih memiliki sangat banyak waktu luang setelah mereka selesai mengerjakan tugastugas rutin rumah tangga. Keterampilan yang mereka miliki untuk mengkreatifitaskan sebuah bahan pangan sangatlah minim karena pengetahuan yang mereka miliki sangatlah sedikit.

Melalui kegiatan pengabdian kepada masyarakat yang merupakan salah satu kegiatan tri dharma perguruan tinggi, penulis mengharapkan dapat memberikan solusi untuk membantu memberikan 
pembelajaran kepada masyarakat kkhususnya ibu-ibu RT 013/01 Kelurahan Pasar Rebo, Jakarta Timur.

Penulis bermaksud memberikan pembelajaran mengenai pembuatan selai labu parang. Oleh karena itu dengan mengikuti pelatihan pembuatan selai labu parang ini sangat berguna mengingat betapa pentingnya tubuh untuk mengkonsumsi makanan sehat, serta untuk menambah pengetahuan agar dapat meningkatkan ekonomi keluarga.

Berdasarkan analisis situasi tersebut di atas, maka diidentifikasi dan dirumuskan masalah sebagai berikut : Apakah pembelajaran pelatihan pembuatan selai labu parang untuk meningkatkan Ekonomi keluarga di RT 013/01 Kelurahan Pasar Rebo, Jakarta Timur dapat bermanfaat?

Tujuan yang diharapkan setelah pelatihan ini adalah warga RT 013/01 Kelurahan Pasar Rebo, Jakarta Timur, terutama ibu-ibu yaitu memiliki pengetahuan tentang membuat selai Labu Parang, memiliki pengetahuan cara mengolah dan menyajikan selai Labu Parang, memilki pengetahuan tentang packaging selai Labu Parang.

Manfaat yang dapat di capai dari kegiatan ini adalah para ibu-ibu RT 013/01 Kelurahan Pasar Rebo, Jakarta Timur memiliki keterampilan dasar dalam pembuatan selai Labu Parang.

\section{MATERI DAN METODE}

Realisasi pemecahan masalah dilakukan dengan mengadakan pelatihan sehingga diharapakan peserta memiliki keterampilan dalam membuat aelai labu parang

Pelatihan yang diberikan kepada IbuIbu PKK ini melalui beberapa tahapan, yaitu: Pemberian materi, Pelatihan, dan Evaluasi.

Khalayak Sasaran adalah Ibu-ibu RT 013/01 kelurahan Pasar Rebo, Jakarta Timur. Lokasi RT 013/01 Kelurahan Pasar
Rebo, Jakarta Timur yang berada dekat dengan pusat kota Jakarta Timur memudahkan tim penerapan iptek dapat memantau hasil dari pembelajaran tersebut. Kegiatan ini merupakan salah satu dari tri dharma perguruan tinggi, yaitu menyebar-luaskan pengetahuan dan keterampilan berupa kegiatan positif bagi khalayak masyarakat sekitar. Kegiatan ini merupakan salah satu daru tri dharma perguruan tinggi, yaitu menyebarluaskan pengetahuan dan keterampilan berupa kegiatan positif bagi khalayak masyarakat sekitar. Dalam kaitannya dengan startegi atau kerangka pemecahan masalah, maka yang menjadi khalayak strategis adalah sebanyak 20 orang peserta yaitu ibu-ibu RT 013/01 Keluraha Pasar Rebo, Jakarta Timur. (daftar hadir peserta yang mengikuti kegiatan pelatihan dilampirkan).

Metode yang digunakan mengingat jenis kegiatan ini adalah praktek dan eksperimen maka metode yang digunakan adalah : $30 \%$ teori berupa ceramah dan $70 \%$ berupa demo dan praktek langsung tentang pembuatan selai labu parang dengan pengawasan dan penjelasan langsung dari tim pelaksana pelatihan.

\section{HASIL DAN PEMBAHASAN}

\section{A. Profile Kelurahan Pasar Rebo}

Kelurahan Pasar Rebo adalah sebuah kelurahan di Jakarta Timur. Kelurahan ini memiliki kode pos 13770. Kelurahan ini memiliki penduduk sebesar 45.203 jiwa (Juli 2012) dan luas wilayah $2,37 \mathrm{Km} 2$.

\section{B. Hasil Pelaksanaan}

Setelah megikuti pelatihan ini peserta memahami bahwa variasi dalam pembuatan selai dapat menggunakan buah labu parang sebagai bahan baku. Selain itu bahan baku yang digunakan membuat selai labu parang sangat terjangkau dan mudah didapat. Tergantung kemauan dari masyarakatnya itu sendiri untuk selalu mencoba dan membuat selai labu parang. 
Dalam pelatihan ini, buah labu parang divariasikan menjadi sirup. Selain membuat selai tidak terlalu sulit, dapat pula dijadikan peluang bisnis yang cukup menjanjikan untuk menambah penghasilan masyarakat itu sendiri. Dalam membuat selai labu parang dibutuhkan ketelitian, kesabaran dan keluletan dalam membuatnya.

Lokasi pelatihan diadakan di Kelurahan Pasar Rebo, Jakarta Timur. Dengan jumlah peserta 20 orang yang berasal dari sosial ekonomi menengah dan rendah.

Kegiatan awal dalam pelatihan ini adalah memberikan materi dan membuat selai labu parang. Selain tahap demi tahap di jelaskan dan dipraktekan. Instruktur pelatihan juga memberikan tips memilih buah labu parang yang dapat digunakan dan juga dalam pemilihan bahan lain serta menyiapkan alat-alat. Kemudian membuat selai labu parang.

\section{KESIMPULAN DAN SARAN}

\section{A. Kesimpulan}

Setelah dilakukan pelatihan keterampilan pelatihan pembuatan selai labu parang, maka peserta yang terdiri dari ibu-ibu RT 013/01 Kelurahan Pasar Rebo, Jakarta Timur memiliki pengetahuan dan keterampilan dalam membuat seli labu parang. Pelatihan berjalan dengan lancar dan peserta antusias dan senang dalam mengikuti proses pelatihan.

\section{B. Saran}

Setelah melakukan kegiatan ini, beberapa hal yang perlu diperhatikan yaitu diperlukannya kerjasama yang berkesinambungan antara pihak Kelurahan Pasar Rebo dengan lembaga pengabdian masyarakat untuk melakukan kegiatankegiatan pelatihan. Mengingat Kelurahan merupakan salah satu jembatan penghubung antara lembaga pengabdian masyarakat dengan warga sehingga dapat meningkatkan pengetahuan dan keterampilan warga, akan tetapi belum ditunjang oleh ketersediannya tenaga ahli dan pelatih yang memadai.

\section{DAFTAR PUSTAKA}

Cara membuat selai pepaya dan nenas. Jakarta : Butsi. Dirjen Pembinaan dan Pengembangan Tenaga Kerja. Direktorat Bina Padat Karya dan Usaha Mandiri, 1983.

Marmalade buah jeruk dan biji. Jakarta : Pusat Penelitian dan Pengembangan Hortikultura, Balitbang Pertanian, 1989.

Lies Suprapti. 2005. Kuaci dan Manisan waluh. Penerbit Kanisius. Yogyakarta

Yudo Sudarto. 2000. Budidaya Waluh. Penerbit Kanisius. Yogyakarta 


\title{
PELATIHAN PEMBUATAN MANISAN KULIT BUAH NAGA DI KELURAHAN KAMPUNG MAKASAR JAKARTA TIMUR
}

\author{
Suci Rahayu \\ Tata Boga, IKK, FT Universitas Negeri Jakarta
}

\begin{abstract}
Dalam upaya pelatihan pembuatan manisan kulit buah naga di kelurahan Kampung Makassar, Jakarta Timur. Dalam pelatihan ini peserta diberikan materi, pengetahuan serta dipraktekan cara membuat manisan kulit buah naga. Khalayak sasaran dari pengabdian ini adalah Ibu-ibu Kelurahan Kampung Makassar, Jakarta Timur. Biaya pengabdian diperoleh dari biaya DIPA PNBP UNJ tahun anggaran 2014. Kegiatan pengabdian telah dilaksanakan pada bulan Agustus yang bertempat di Kelurahan Kebon Pala yang dihadiri oleh 30 peserta. Setiap peserta pada awalnya diberikan penyuluhan serta manfaat kulit buah naga serta membuat manisan kulit buah naga. Latihan ini bertujuan untuk melatih peserta dalam meningkatkan kreatifitasnya dan meningkatkan ekonomi keluarga dengan keterampilan yang didapat. Dari hasil evaluasi diperoleh hasil dan manfaat dari kegiatan pengabdian ini diantaranya adalah kemampuan ibu-ibu untuk membuat manisan kulit buah naga.
\end{abstract}

Kata Kunci : Buah Naga, Ibu-ibu Kelurahan Makasar

\section{PENDAHULUAN}

Indonesia memiliki kekayaan sumber daya hayati tropika yang unik, kelimpahan sinar matahari, air dan tanah dan juga potensi pertanian organik yang sangat besar. Luas lahan pertanian yang mencapai 50 Juta hektar memungkinkan berkembangnya berbagai produk organik ramah lingkungan yang mampu menjadikan keunggulan komparatif dengan negara lain, meskipun belum termanfaatkan secara maksimal. Salah satunya adalah buah naga, masyarakat di Indonesia sudah lebih mengenal buah naga.

Berdasarkan hal tersebut, biasanya masyarakat hanya mengkonsumsi daging buah naga, dan membuang kulit nya, padahal kulit buah naga tersebut dapat menjadi variasi makanan baru untuk meningkatkan ekonomi Indonesia.
Kulit buah naga atau yang memiliki nama ilmiah Hylocereus Undotus ini memiliki banyak kandungan yang berguna bagi tubuh, maka dari itu tak jarang buah ini banyak diolah menjadi berbagai jenis olahan agar dapat dikonsumsi .Pelatihan pembuatan manisan kulit buah manggis sangat diharapkan di Kelurahan Kampung Makasar Jakarta Timur. Minimnya pengetahuan warga kelurahan kampung Makasar khususnya ibu-ibu dalam mengolah limbah kulit buah naga sehingga diperlukan adanya pelatihan ini.

Kulit buah naga merupakan limbah dari buah naga yang biasanya dibuang begitu saja oleh masyarakat, tetapi sebenarnya kulit buah naga memiliki nilai ekonomis yang tinggi setelah diolah menjadi suatu produk olahan.

Ditinjau dari segi ekonomi masyarakat Kelurahan Kampung Makasar 
merupakan masyarakat dengan pendapatan ekonomi menengah ke bawah, dimana sebagian besar kepala keluarga bekerja sebagai buruh, sedangkan para istri adalah ibu rumah tangga yang lebih banyak menghabiskan waktu di rumah.

Ibu-ibu rumah tangga di Kelurahan Kampung Makasar umumnya masih memiliki sangat banyak waktu luang setelah mereka selesai mengerjakan tugastugas rutin rumah tangga. Sehingga untuk mengisi waktu luang itu ibu-ibu kampong Makasar bisa mengikti pelatihan pembuatan manisan kulit buah naga, untuk menambah keterampilan mereka dan meningkatakan perekonomian mereka dengan membuka usaha manisan kulit buah manggis. Khalayak sasaran yaitu 30 orang ibu warga Kelurahan Kampung Makasar.

Berdasarkan analisis situasi tersebut di atas, maka diidentifikasi dan dirumuskan masalah sebagai berikut : Apakah pembelajaran pelatihan pembuatan manisan kulit buah naga untuk meningkatkan ekonomi keluarga di Kelurahan Kampung Makasar, Jakarta Timur dapat bermanfaat?

Tujuan yang diharapkan setelah pelatihan ini adalah warga Kelurahan Kampung Makasar terutama ibu-ibu yaitu, memiliki pengetahuan tentang membuat manisan kulit buah naga., memiliki pengetahuan cara mengolah dan menyajikan manisan kulit buah naga., memilki pengetahuan tentang packaging manisan kulit buah naga.

Manfaat yang dapat di capai dari kegiatan ini adalah para ibu-ibu kelurahan kampung Makasar memiliki keterampilan dasar dalam pembuatan manisan kulit buah naga.

\section{MATERI DAN METODE}

Realisasi pemecahan masalah dilakukan dengan mengadakan pelatihan sehingga diharapakan peserta memiliki keterampilan dalam membuat sirup bunga rosela.

Pelatihan yang diberikan kepada IbuIbu PKK ini melalui beberapa tahapan, yaitu: Pemberian materi, Pelatihan, dan Evaluasi.

Khalayak Sasaran adalah Ibu-ibu Kampung Makassar, Jakarta Timur. Lokasi kelurahan yang berada berdekatan dengan pusat kota Jakarta timur memudahkan tim penerapan iptek dapat memantau hasil dari pembelajaran tersebut. Kegiatan ini merupakan salah satu daru tri dharma perguruan tinggi, yaitu menyebarluaskan pengetahuan dan keterampilan berupa kegiatan positif bagi khalayak masyarakat sekitar. Dalam kaitannya dengan startegi atau kerangka pemecahan masalah, maka yang menjadi khalayak strategis adalah sebanyak 30 orang ibu-ibu Kampung Makssar Jakarta Timur. (daftar hadir peserta yang mengikuti kegiatan pelatihan dilampirkan).

Metode yang Digunakan Mengingat jenis kegiatan ini adalah praktek dan eksperimen maka metode yang digunakan adalah : $30 \%$ teori berupa ceramah dan $70 \%$ berupa demo dan praktek langsung tentang pembuatan selai labu parang dengan pengawasan dan penjelasan langsung dari tim pelaksana pelatihan.

\section{HASIL DAN PEMBAHASAN}

\section{A. Profile Kampung Makassar}

Kelurahan ini memiliki kode pos 13650.Kelurahan ini memiliki penduduk sebesar 37.226 jiwa (Desember 2008) dan luas wilayah 2,29 Km 22. 


\section{Hasil Pelaksanaan}

Setelah megikuti pelatihan ini peserta memahami bahwa variasi dalam pembuatan manisan dapat digunakan limbah kulit buah naga sebagai bahan baku. Selain itu bahan baku yang digunakan membuat manisan kulit buah naga sangat terjangkau dan mudah didapat. Tergantung kemauan dari masyarakatnya itu sendiri untuk selalu mencoba dan membuat manisan kulit buah naga.

Dalam pelatihan ini, kulit buah naga dimanfaatkan menjadi manisan. Selain membuat manisan tidak terlalu sulit, dapat pula dijadikan peluang bisnis yang cukup menjanjikan untuk menambah penghasilan masyarakat itu sendiri. Dalam membuat manisan kulit buah naga dibutuhkan ketelitian, kesabaran dan keuletan dalam membuatnya.

Lokasi pelatihan diadakan di Kelurahan Kampung Makassar, Jakarta Timur. Dengan jumlah peserta 30 orang yang berasal dari sosial ekonomi menengah dan rendah.

Kegiatan awal dalam pelatihan ini adalah memberikan materi dan membuat manisan kulit buah naga. Selain tahap demi tahap di jelaskan dan dipraktekan. Instruktur pelatihan juga memberikan tips memilih kulit buah naga yang dapat digunakan dan juga dalam pemilihan bahan lain serta menyiapkan alat-alat. Kemudian membuat manisan kulit buah naga.

\section{KESIMPULAN DAN SARAN}

\section{Kesimpulan}

Setelah dilakukan pelatihan keterampilan pemanfaatan kulit buah naga untuk manisan, maka peserta yang terdiri dari ibu-ibu Kelurahan Kampung Makassar, memiliki pengetahuan dan keterampilan dalam membuat manisan kulit buah naga. Pelatihan berjalan dengan lancar dan peserta antusias dan senang dalam mengikuti proses pelatihan.

\section{Saran}

Setelah melakukan kegiatan ini, beberapa hal yang perlu diperhatikan yaitu diperlukannya kerjasama yang berkesinambungan antara pihak Kelurahan Kampung Makassar dengan lembaga pengabdian masyarakat untuk melakukan kegiatan-kegiatan pelatihan. Mengingat Kelurahan merupakan salah satu jembatan penghubung antara lembaga pengabdian masyarakat dengan warga sehingga dapat meningkatkan pengetahuan dan keterampilan warga, akan tetapi belum ditunjang oleh ketersediannya tenaga ahli dan pelatih yang memadai.

\section{DAFTAR PUSTAKA}

Hardjadinata, Ir. Sinatra. Budi Daya Buah Naga Super Red secara Organik. Penebar Swadaya Depok. 2010

Muaris H. 2003. Manisan buah. Jakarta: Gramedia Pustaka Utama.

Fatah MA, Bachtiar Y. 2004. Membuat aneka manisan buah. Jakarta: AgroMedia Pustaka 